\title{
Hubungan Konsentrasi Kromium (Cr) dalam Air Sumur dengan Konsentrasi pada Urin dan Rambut Warga Dusun Banyakan Yogyakarta
}

\author{
Correlation between Concentration of Chromium (Cr) in Wells Water, Urine and \\ Hair of Resident of Banyakan Village Yogyakarta
}

\author{
Yoseph Junedi $\mathrm{Poa}^{1}$, Djoko Rahardjo ${ }^{1^{*}}$, dan Kisworo ${ }^{1}$
}

Fakultas Bioteknologi, Universitas Kristen Duta Wacana, Yogyakarta, Indonesia

\begin{abstract}
Abstrak
Aktivitas pembuangan limbah cair industri penyamakan kulit di dusun Banyakan memiliki dampak negatif bagi lingkungan. Masuknya pencemar kromium kedalam air sumur adalah salah satu dampak negatif tersebut. Tujuan dari penelitian ini adalah untuk mengetahui konsentrasi kromium dalam air sumur, rambut dan urin warga setempat. Penelitian dilakukan di Dusun Banyakan, Kabupaten Bantul, Provinsi Daerah Istimewa Yogyakarta. Sampel yang diambil adalah sampel air sumur, urin dan rambut. Ektraksi sampel menggunakan metode destruksi aqua regia $\left(3 \mathrm{HNO}_{3}+\mathrm{HCl}\right)$ selanjutnya analisa konsentrasi kromium menggunakan instrumen AAS (Atomic Absorption Spectrophotometry). Pencemar kromium ditemukan pada semua sampel, baik air sumur, rambut dan urin. Sampel rambut memiliki konsentrasi kromium paling tinggi dengan rerata sebesar $0,4685 \mathrm{Mg} / \mathrm{Kg}$, diikuti sampel urin dengan rerata $0,0007 \mathrm{Mg} / \mathrm{L}$ dan terendah pada sampel air sumur dengan rerata $0,0007 \mathrm{Mg} / \mathrm{L}$. Konsentrasi kromium pada rambut dan urin didapati melebihi standar baku mutu. Paparan yang diterima warga rata-rata per harinya adalah 0,10125 $\mu \mathrm{g} / \mathrm{L}$ serta tidak ada hubungan antara asupan harian kromium dengan konsentrasi kromium pada urin dan rambut.
\end{abstract}

Kata kunci : Krom, air sumur, urin, rambut, Banyakan

\begin{abstract}
The activities of the leather tanning industry have a negative impact on the environment. The purpose of this study was to determine the chromium concentration in wells water, hair and urine. The research was conducted at the Banyakan Village (I, II and III), Regency of Bantul, Province of Daerah Istimewa Yogyakarta Collected samples consist of wells water, and urine and hair from local residence. Extraction of samples used aqua regia $\left(3 \mathrm{HNO}_{3}+\mathrm{HCl}\right)$ digestion method and chromium concentration were analized using the AAS (Atomic Absorption Spectrophotometry) instrument. Hair samples showed the highest accumulation of chromium with an average value of $0.4685 \mathrm{Mg} / \mathrm{Kg}$, meanwhile urine samples showed average value of $0.0007 \mathrm{Mg} / \mathrm{L}$ and well water samples had accumulated chromium with average value of $0.0007 \mathrm{Mg} / \mathrm{L}$. Both of chromium accumulation in resident hair and urine was surpassing standard quality value. The daily chromium intake rate of Banyakan Village resident is $0.10125 \mu \mathrm{g} / \mathrm{L}$, and there is no correlation between chromium daily intake and concentrations of chromium in urine and hair of resident.
\end{abstract}

Keywords: Chromium, wells water, urine, hair, Banyakan

\footnotetext{
*Corresponding author:

Djoko Rahardjo

Fakultas Bioteknologi, Universitas Kristen Duta Wacana

Jl. Wahidin Sudirohusodo 5-25, Yogyakarta, Indonesia, 55224

E-mail : djoko@staff.ukdw.ac.id
} 


\section{Pendahuluan}

Daerah Yogyakarta merupakan salah satu daerah dengan pertumbuhan industri yang tinggi. Oleh karena itu pemerintah daerah Daerah Istimewa Yogryakarta telah menetapkan Kawasan Industri Piyungan sebagai sentra industri dan pusat pertumbuhan ekonomi bari di provinsi DIY. Hadirnya kawasan industri di desa Banyakan dan kecamatan Piyungan secara umum, selain mampu menggerakan perekonomian, memberikan lapangan pekerjaan namun juga berpotensi menimbulkan gangguan lingkungan. Hingga saat ini dikawasan industri piyungan terdapat lebih kurang 12 industri dan 10 diantaranya adalah industri kulit. Dari 10 industri kulit tersebut hanya 1 industri yang melakukan pengolahan limbah sudah relatif baik, sementara industri lainnya belum melakukan pengolahan limbah bahkan belum memiliki dokumen Upaya Pengelolaan Lingkungan Hidup dan Upaya Pemantauan Lingkungan Hidup (UKLUPL) (Anonim, 2017). Aktivitas produksi dan pembuangan limbah cair industri kulit lingkungan berpotensi menyebakan terdistribusinya pencemar kromium keberbagai komponen lingkungan, salah satunya yaitu ke air sumur. Hasil penelitian Rahardjo (2014), menumukan bahwa cemaran kromium air sumur dengan rerata $1,538 \mathrm{mg} / \mathrm{l}$ dan konsentrasi terus meningkat pada tahun 2016 menjadi sebesar 8,83 mg/1 (Rahardjo, 2016). Pencemar kromium selain ditemukan pada air sumur juga ditemukan terakumulasi pada rambut warga yang tinggal disekitar kawasan industri dengan kisaran 0,024-1,904 mg/Kg (Rahardjo, 2014). Tingginya konsentrasi kromium dalam air sumur dan rambut disebabkan oleh aktivitas pembuangan air limbah melalui saluran irigasi yang melewati kawasan pemukiman di dusun Banyakan. Pencemaran kromium yang ada dalam air limbah dan saluran irigasi dapat masuk kedalam sumursumur warga melalui proses infiltrasi. Kromium bersifat karsinogenik dan dapat menggangu sistem metabolisme pada tubuh. Dalam konsentrasi yang rendah kromium merupakan mineral yang diperlukan tubuh. Kromium mampu terabsorpsi dalam tubuh manusia memanfaatkan komponenkomponen lingkungan seperti air, tanah dan udara. Air menjadi salah satu medium penyaluran kromium yang paling banyak kasusnya.

Kecenderungan meluasnya distribusi serta meningkatnya konsentrasi dan akumulasi kromium di lingkungan menjadi ancaman potensial bagi lingkungan dan kesehatan masyarakat di sekitar kawasan industri. Tidaklah mengherankan bila aktivitas pembuangan limbah industri kulit ke saluran irigasi mendapatkan protes oleh warga dengan melakukan penutupan saluran pembuangan limbah dan pelarangan pembuangan limbah cair ke saluran irigasi. Oleh karena itu pihak industri dan difasilitasi oleh pemerintah daerah membuat saluran pembuangan limbah baru dengan sistem perpipaan dan langsung masuk ke aliran sungai Opak. Adanya perubahan aliran pembuangan limbah yang baru perlu diikuti dengan program monitoring lingkungan dan manusia yaitu dengan melakukan pengujian konsentrasi dan akumulasi kromium dalam air sumur, rambut dan urin warga dusun banyakan. Diharapkan dengan program monintoring ini akan diketahui konsentrasi kromium dalam air sumur dan hubungannya dengan konsentrasi kromium dalam sampel rambut dan urin.

\section{Materi Dan Metode Lokasi}

Pengambilan sampel air sumur, urin dan rambut, dilakukan di Dusun Banyakan I, II dan III, Desa Sitimulyo, Kecamatan Piyungan, Kabupaten Bantul, Daerah Istimewa Yogyakarta.

\section{Koleksi Sampel}

Sampel yang digunakan adalah air sumur, urin, dan rambut. Pengambilan air sumur dilakukan dengan menggunakan Heyroth water sampler (untuk sumur timba) dan Botol HDPE untuk jenis sumur listrik (diambil langsung dari keran). Uji Parameter yang dilakukan adalah pengukuran suhu, $\mathrm{pH}$, serta melakukan wawancara kuisioner pola konsumsi air minum. 


\section{Preparasi Sampel}

Sampel rambut ditimbang untuk mengetahui berat basah kemudian direndam dengan ekstran selama 10-15 menit. Setelah direndam, sampel rambut lalu dioven pada suhu $60^{\circ} \mathrm{C}$ selama 2 jam, kemudian dianginanginkan sebelum ditimbang berat kering. Sampel rambut lalu dipotong kecil-kecil dengan gunting kemudian dihaluskan menggunakan mortar. Untuk sampel sampel air sumur dan urin hanya dimasukan ke dalam lemari pendingin sebelum diekstrasi. Khusus untuk sampel urin, diberi penambahan Aquadest hingga mencapai $100 \mathrm{ml}$ menggunakan gelas ukur, sebelum diekstraksi.

\section{Ekstraksi}

Proses ekstraksi terbagi menjadi ektraksi non dekstruksi $\left(\mathrm{HNO}_{3}: \mathrm{H}_{2} \mathrm{O} ; \mathrm{v} / \mathrm{v}\right)$ dan ekstraksi dekstruksi yaitu dengan penambahan aqua regia $\left(\mathrm{HCl}: \mathrm{HNO}_{3} ; 3: 1 \mathrm{v} / \mathrm{v}\right)$

\section{Hasil}

Tabel 1 menunjukan bahwa mayoritas sumur warga berupa sumur bor, dengan karakteristik kualitas air secara visual tidak berwarna, tidak berbau dengan kisaran suhu 29-33 ${ }^{\circ} \mathrm{C}$, dan $\mathrm{pH} 6,30-7,80$. Nilai masih sesuai dengan persyaratan sebagai air minum.

Tabel 1. Karakteristik dan kualitas air sumur

\begin{tabular}{clll}
\hline Parameter & \multicolumn{1}{c}{ B-I } & \multicolumn{1}{c}{ B-II } & \multicolumn{1}{c}{ B-III } \\
\hline Suhu & $29-32^{\circ} \mathrm{C}$ & $27-31^{\circ} \mathrm{C}$ & $27-33^{\circ} \mathrm{C}$ \\
Jenis Sumur & Sumur bor & Sumur bor & Sumur bor \\
& Tidak & Tidak & Tidak \\
Warna & berwarna & berwarna & berwarna \\
& Tidak & Tidak & Tidak \\
Bau & berbau & berbau & berbau \\
pH & $6,30-7,5$ & $6,60-7,80$ & $6,40-7,5$ \\
\hline
\end{tabular}

Tabel. 2 Rerata konsentrasi kromium sampel air sumur, urin dan rambut

\begin{tabular}{ccccc}
\hline Sampel & B-I & B-II & B-III & Rerata Total \\
\hline Air Sumur & 0,0007 & 0,0007 & 0,0007 & 0,0007 \\
Urin & 0,0007 & 0,0007 & 0,0007 & 0,0007 \\
Rambut & 0,3061 & 0,5111 & 0,5884 & 0,4685 \\
\hline
\end{tabular}

Pada tabel 2 diketahui bahwa semua sampel air sumur, rambut dan urin warga dusun Banyakan ditemukan pencemar kromium. Konsensentrasi tertingi ditemukan pada sampel rambut $(0,5884 \mathrm{Mg} / \mathrm{Kg})$, dan

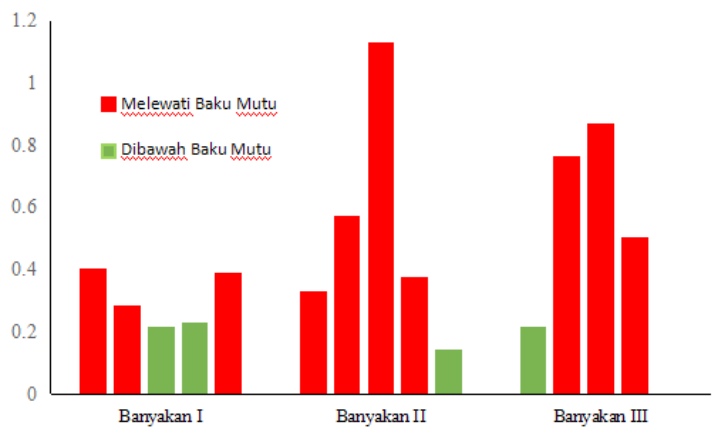

Gambar 1. Konsentrasi kromium pada rambut

diikuti oleh sampel sampel urin $(0,0007$ $\mathrm{Mg} / \mathrm{L}$ ) dan terendah pada sampel air sumur $(0,0007 \mathrm{Mg} / \mathrm{L})$.

Konsentrasi kromium pada sampel air sumur ditemukan relatif sama antar dusun yang diamati. Sementara untuk konsentrasi kromium pada rambut dan urin bervariasi antar ketiga dusun. Gambar 2 menunjukkan bahwa, konsentrasi kromium dalam rambut ditemukan tertinggi pada dusun Banyakan II, kemudian diikuti Banyakan III dan terendah pada dusun Banyakan I. Akumulasi kromium pada rambut telah telah melewati standar baku mutu yang ditetapkan ASTDR (2012) yaitu 0,234 Mg/Kg.

Berdasar analisis data dari kuisener diketahui laju asupan harian (daily intake) kromium pada warga Dusun Banyakan. Dosis paparan yang diterima warga ratarata per harinya adalah 0,10125 $\mu \mathrm{g} / \mathrm{L}$. Laju asupan ini masih termasuk dalam kategori aman bagi kesehatan.

Tabel 3. Asupan kromium harian

\begin{tabular}{cccc}
\hline B-I & B-II & B-III & $\boldsymbol{\Sigma}$ DI \\
\hline 0,0152 & 0,0168 & 0,06925 & 0,10125 \\
$\mu \mathrm{g} / \mathrm{L}$ hari & $\mu \mathrm{g} / \mathrm{L}$ hari & $\mu \mathrm{g} / \mathrm{L}$ hari & $\mu \mathrm{g} / \mathrm{L}$ hari \\
\hline
\end{tabular}

Tabel 4 menunjukan hubungan antara konsumsi harian dengan konsentrasi pada urin dan rambut. Hasilnya adalah tidak ditemukan hubungan antar asupan kromium harian dengan konsentrasi kromium pada urin dan rambut.

Tabel 4. Korelasi asupan kromium harian dengan konsentrasi kromium pada urin dan rambut

\begin{tabular}{cc}
\hline sig & r \\
\hline $0,234>0,05$ & $-0,340$ \\
\hline
\end{tabular}




\section{Pembahasan}

Konsentrasi Krom dalam Air Sumur dan Urin

Konsentrasi kromium pada air sumur adalah 0,0007 Mg/L, digolongkan dalam batas aman konsumsi berdasarkan Permenkes No. 492/Menkes/Per/IV/ 2010 tentang Persyaratan Kualitas Air Minum yaitu maksimum sebesar 0,05 $\mathrm{Mg} / \mathrm{L}$. Turunnya konsentrasi kromium pada air sumur dipengaruhi oleh perubahan aliran pembuangan limbah cair industri kulit, semula jalur pembuangan limbah melewati kawasan permukiman, berdasarkan penelitian yang dilakukan Rahardjo (2014; 2015), sehingga konsentrasi kromium pada sumur realtif tinggi. Perubahan konsentrasi terjadi setelah perubahan aliran limbah pada tahun 2018 konsentrasi krom pada air sumur berangsur-angsur menurun.

Selain perubahan aliran limbah, penurunan konsentrasi kromium ini dipengaruhi oleh faktor fisik dan kimia. Suhu air sumur warga berkisar pada $27^{\circ} \mathrm{C}-33^{\circ} \mathrm{C}$ dan masuk dalam golongan suhu optimal. Menurut Harsianti dan Nurasia (2016), Suhu air yang normal akan menandakan bahwa toksisitasnya rendah. Semakin tinggi suhu air sumur maka kadar toksisitas dari kromium meningkat. Parameter lain seperti warna dan bau memiliki hasil yang normal dan sesuai dengan Permenkes No. 492/ Menkes/Per/IV/2010 tentang Persyaratan Kualitas Air Minum. Secara keseluruhan sumur yang digunakan oleh warga adalah sumur bor dengan sistem perpipaan jenis polyvinil chloride (PVC). Menurut penelitian yang dilakukan oleh Munfiah et al. (2013), kualitas fisik dan kimia sumur bor lebih baik dibandingkan dengan sumur gali. Sumur bor meminimalisir kontak air dengan tanah yang telah terkontaminasi kromium sehingga konsentrasi kromium pada air sumur rendah. Sumawijaya et al. (2020), menyatakan bahwa air tanah dapat terkontaminasi apabila terjadi kontak dengan tanah yang mengadsorpsi kromium melalui sebuah proses yang disebut desorpsi. Faktor lainnya yaitu nilai derajat keasaman $(\mathrm{pH})$, pada air sumur berkisar 6,30-7,80. Nilai ini termasuk dalam golongan $\mathrm{pH}$ netral. $\mathrm{pH}$ netral menandakan bahwa air sumur memiliki toksisitas yang rendah. Sebaliknya pada $\mathrm{pH}$ asam maka toksitas kromium akan semakin besar .

Kromium pada urin menggambarkan paparan kromium yang diterima selama 1-2 hari. Sumber makanan atau minuman tersebut kemudian masuk ke sistem pencernaan kemudian menuju organ ekskresi. Menurut Wulaningtyas (2018), kromium mengalami penumpukan pada organ ginjal, penumpukan ini semakin diperparah apabila terjadi gangguan fungsi ginjal. Batas konsentrasi kromium pada makanan atau minuman yang dikonsumsi adalah 50-200 $\mu \mathrm{g}$ per hari (Wulaningtyas, 2018). Diketahui konsentrasi kromium pada urin responden adalah 0,0007 Mg/L. Menurut ATSDR (2008), batas konsentrasi kromium pada urin adalah $0,00022 \mathrm{Mg} / \mathrm{L}$ atau 0,22 $\mathrm{gg} / \mathrm{L}$, maka dapat disimpulkan bahwa konsentrasi kromium pada urin responden Dusun Banyakan telah melewati baku mutu yang ditetapkan. Jumlah kromium yang meningkat pada urin dapat disebakan faktor lain seperti inhalasi dan pemaparan melalui lapisan kulit, pemaparan kromium tidak selalu secara oral (melalui makanan atau minumun). Proses pemaparan jalur inhalasi sebanyak 53-85\% akan diserap melalui paru-paru ke dalam sistem darah kemudian diekskresikan oleh ginjal dan hati. Ginjal akan menyerap kromium dari darah melalui korteks dan melepaskannya ke dalam urin (Sudarsana et al. 2013).

\section{Konsentrasi Krom pada Rambut}

Konsentrasi kromium pada rambut memiliki rata-rata $0,3061 \mathrm{Mg} / \mathrm{Kg}$ pada Banyakan I, 0,5111 Mg/Kg pada Banyakan II, dan $0,5884 \mathrm{Mg} / \mathrm{Kg}$ pada Banyakan III (lihat tabel 2). Perbedaan konsentrasi kromium antar dusun menurut Azni et al. (2015), dipengaruhi oleh perbedaan variabel umur dan berat badan akan mempengaruhi laju inhalasi pada tubuh sehingga berpengaruh pada hasil konsentrasi kromium yang diperoleh. Tingginya konsentrasi kromium pada rambut disebabkan karena Rambut merupakan bioindikator dalam jangka waktu panjang (long-term retention) sehingga akumulasi yang dihasilkan berpotensi lebih tinggi jika dibandingkan dengan bioindikator lain (Rahardjo, 2018). 
Rentangan konsentrasi kromium pada rambut pada Banyakan II dan III lebih besar nilainya jika dibandingkan dengan Banyakan I. Standar baku mutu konsentrasi kromium dalam rambut menurut ATSDR (2012), adalah $0,234 \mathrm{Mg} / \mathrm{Kg}$. Berdasarkan standar baku mutu tersebut, sebagian besar responden memiliki konsentrasi kromium yang telah melewati batas. Dusun Banyakan II dan III sebagai wilayah dengan jumlah akumulasi paling tinggi yaitu 7 dari 9 responden telah terpapar kromium dengan konsentrasi yang telah melewati baku mutu. Rambut merupakan bagian dari tubuh manusia yang terletak diluar tubuh. Masuknya kromium pada jaringan rambut dapat disebabkan oleh beberapa faktor seperti, penggunaan peralatan kerja pabrik yang masih tidak sesuai SOP (Standard Operating Procedure). Selain buruh pabrik, beberapa pekerjaan lain seperti tukang dan montir pun berpengaruh terpapar kromium yang berasal dari asap kendaraan bermotor maupun cat semprot. Kromium akan mengendap pada kulit kepala terserap melalui lapisan dermal atau menempel pada jaringan rambut (Rahardjo, 2018).

Akumulasi kromium paling banyak terakumulasi pada rambut. Rerata total dari 3 sampel tersebut adalah $0,0007 \mathrm{Mg} / \mathrm{Kg}$ untuk air sumur dan urin, serta $0,4685 \mathrm{Mg} /$ Kg untuk rambut.

\section{Asupan Kromium Harian}

Pada tabel 3 diketahui besaran paparan harian pada Banyakan III memiliki nilai paling tinggi rata-ratanya yaitu $0,06925 \mu$ / $\mathrm{Kg} /$ hari diikuti Banyakan II 0,0168 $\mu / \mathrm{Kg} /$ hari dan Banyakan I 0,0152 $\mu / \mathrm{Kg} /$ hari. Perbedaan dosis paparan harian dipengaruhi oleh perbedaan berat badan dan konsumsi air per harinya. Perbedaan berat badan akan mempengaruhi laju inhalasi pada tubuh sehingga berdampak pada hasil konsentrasi kromium yang masuk ke dalam tubuh. Selain itu konsumsi air setiap responden berbedabeda. Menurut Wulaningtyas (2018), batas paparan harian kromium adalah 0,05-0,2 $\mathrm{Mg} / \mathrm{Kg}$. Apabila dibandingkan dengan nilai ini maka paparan kromium di Dusun Banyakan sangat rendah. Paparan kromium yang rendah ini bisa saja mengalami kenaikan apabila konsumsi bahan makanan yang mengandung kromium masih dilakukan.

\section{Korelasi Asupan Harian Kromium dengan Konsentrasi Kromium pada Urin dan Rambut}

Korelasi antara asupan harian dengan konsentrasi kromium dilakukan pada responden 14 orang $(n=14)$, diperoleh nilai korelasi sederhana (r) sebesar -0,340. Hasil ini menyatakan bahwa hubungan antara pola konsumsi air minum dengan konsentrasi kromium pada rambut rendah. Sedangkan arah hubungan yang terjadi adalah negatif karena nilai $r$ negatif, berarti semakin banyak jumlah air yang diminum tidak meningkatkan konsentrasi kromium pada rambut. Selain korelasi, dilakukan juga uji signifikansi untuk mengetahui apakah hubungan yang terjadi dapat berlaku dalam suatu populasi tertentu. Nilai signifikansi yang diperoleh dalam uji korelasi ini adalah sig $=0,234$, nilai $0,234>0,05$ yang berarti tidak ada hubungan antara pola konsumsi air dengan konsentrasi kromium pada rambut.

\section{Kesimpulan}

Konsentrasi kromium pada rambut dan urin telah melebihi standar baku mutu $(0,5884 \mathrm{Mg} / \mathrm{Kg}$ untuk rambut dan 0,0007 $\mathrm{Mg} / \mathrm{L}$ untuk urin), sedangkan air sumur masih berada dibawah baku mutu $(0,0007$ $\mathrm{Mg} / \mathrm{L}$ ), dengan laju asupan kromium harian berada dibawah baku mutu yaitu 0,10125 $\mu \mathrm{g} / \mathrm{L}$ hari, serta tidak ada hubungan antara asupan harian kromium dengan konsentrasi kromium pada urin dan rambut.

\section{Daftar Pustaka}

Agency for Toxic Substances and Disease Registry. (2008). Toxicological Profile for Chromium. Department Of Health and Human Services. United State of America.

Agency for Toxic Substances and Disease Registry. (2012). Toxicological Profile for Chromium. Department Of Health and Human Services. United State of America.

Anonim. (2017). Profil Kawasan Peruntukan Industri Piyungan Kabupaten Bantul 
Poa et al.

Daerah Istimewa Yogyakarta. Dinas Perindustrian, Perdagangan dan Koperasi. Bantul. D.I. Yogyakarta.

Azni, I. N., Wispriono, B., \& Meliana, S. (2015). Analisis Risiko Kesehatan Pajanan $\mathrm{PM}_{10}$ Pada Pekerja Industri READYMIX PT. X Plant Kebon Nanas Jakarta Timur.Jurnal Media Kesehatan Masyarajat Iindonesia, 203-209.

Harsianti \& Nurasia. (2016). Analisis Warna, Suhu, pH, dan Salinitas Air Sumur Bor di Kota Palopo. Prosiding Seminar Nasional.II(1), hlm. 747-753.

Munfiah, S., Nurjazuli., \& Onny, S. (2013). Kualitas Fisik dan Kimia Air Sumur Gali dan Sumur Bor di Wilayah Kerja Puskesmas Guntur II Kabupaten Demak.Jurnal Kesehatan Lingkungan Indonesia. XII(21).

Peraturan Menteri Kesehatan RI No.492/ MENKES/PER/IV/2010 tentang peryaratan kualitas air minum.

Rahardjo, D. (2014). Profil cemaran krom pada air permukaan, sedimen, air tanah, dan biota serta akumulasi pada rambut dan kuku warga masyarakat di sekitar kawasan industri penyamakan kulit Desa Banyakan. Lembaga Penelitian dan Pengabdian Masyarakat Universitas Kristen Duta Wacana Yogyakarta.

Rahardjo, D. (2015). Profil Cemaran Kromium di Lingkungan serta Konsentrasi dan Akumulasinya dalam Darah dan Rambut. Laporan Penelitian. Fakultas Bioteknologi UKDW.

Rahardjo, D. (2016). Profil Cemaran Kromium di Lingkungan serta Konsentrasi dan Akumulasinya dalam Darah dan Rambut. Laporan Penelitian. Fakultas Bioteknologi UKDW.

Rahardjo, D. (2018). Konsentrasi dan Akumulasi Kromium dalam Darah dan Rambut Warga Desa Banyakan. Prosiding Seminar Nasional Biologi dan Pembelajarannya Universitas Negeri Medan.

Sudarsana, E., Onny, S., Suhartono. (2013). Hubungan Riwayat Pajanan Kromium dengan Gangguan Fungsi Ginjal pada Pekerja Pelapisan Logam di Kabupaten
Sciscitatio, Vol. 2, No. 1, Januari 2021

Tegal. Jurnal Kesehatan Lingkungan Indonesia. XXII(1),34-41.

Sumawijaya, N., Mulyono, A., \& Rusdi, A. F. (2020).Studi Kemampuan Adsorpsi Ion Logam $\mathrm{Cr}^{6+}$ oleh Tanah Vulkanik Studi Kasus Wilayah Industri Penyamakan Kulit, Garut. Jurnal Teknologi Lingkungan. XXI(1),125-130.

Wulaningtyas \& Febri Ayu. (2018). Karakteristik Pekerja Kaitannya dengan Kandungan Kromium dalam Urine Pekerja di Industri Kerupuk Rambak Magetan.Jurnal Kesehatan Lingkungan. (1), 127-137. 